\title{
Understanding of Tobacco and Lung Cancer Among Medical Students in Kathmandu University School of Medical Sciences (KUSMS)
}

\author{
Khatiwada $P,{ }^{1}$ Kayastha $S R,{ }^{2}$ Pant $P,{ }^{2}$ Khanal $K R,{ }^{2}$ Giri $A,{ }^{1}$ Khatiwoda $P,{ }^{1}$ Mali $A^{3}$
}

\author{
${ }^{1}$ Richa Bajimaya Memorial Foundation \\ Kathmandu, Nepa \\ ${ }^{2}$ Kathmandu University School of Medical Sciences \\ Dhulikhel, Nepal \\ ${ }^{3}$ Nidan, Kathmandu, Nepal
}

Corresponding Author

Prashant Khatiwada

Richa Bajimaya Memorial Foundation

Kathmandu, Nepal

E-mail: prashant@nidan.org.np

\section{Citation}

Khatiwada P, Kayastha SR, Pant P,Khanal KR, Giri A, Khatiwoda $P$ et.al. Understanding of Tobacco and Lung Cancer Among Medical Students in Kathmandu University School of Medical Sciences (KUSMS) Kathmandu Univ med J 2012;39(3):60-65.

\section{ABSTRACT \\ Background}

Often, lung cancer is diagnosed at terminal stages. Poor awareness about the symptoms or risk factors of lung cancer among medics may be one of the factors for delayed diagnosis.

\section{Objective}

We explored the knowledge of medical students and their behavior with the patients of lung cancer.

\section{Method}

Qualitative and quantitative approaches were used for data collection from 153 medical student of Kathmandu University School of Medical Sciences from December 2011 to May 2012.

\section{Results}

Among the results, eighty-nine students had over $80 \%$ knowledge of the 14 cancer warning signs, among them $83 \%$ knew the nine risk factors for lung cancer. Twenty-three students told lung cancer can be hereditary. Sixty five percent of all participants believed that lung cancer can be detected at early stage; of them $81 \%$ told that it can be treated. About $24 \%$ of the total students were current or exsmokers and about half of them believed that lung cancer does not occur in light smokers. Only $10 \%$ have heard of Framework Convention on Tobacco Control in Nepal.

\section{Conclusion}

Study finds that all medical students who know about any cancers may not necessarily have knowledge about lung cancers. Their perception about the cause of lung cancer may be influenced by their smoking behavior and there was little knowledge of public health measures for smoking control. Awareness about national policies needs to be increased.

\section{KEY WORDS}

knowledge, lung neoplasm, medical education, smoking, tobacco

\section{INTRODUCTION}

Lung cancer is the most common cancer worldwide, with an estimated 1,600,000 new cases and 1,380,000 deaths in 2008..$^{1,2}$ Seventy five percent of patients with lung cancer present with symptoms due to advanced local or metastatic disease that is not amenable to cure. ${ }^{3}$ Despite advances in therapy, five-year survival rates average approximately 16 $\%$ for all individuals with lung cancer., ${ }^{2,4}$ Prevention, rather than screening, is the most effective strategy for reducing the burden of lung cancer. The promotion of smoking cessation is essential, as cigarette smoking is felt to be causal in almost $90 \%$ of all lung cancer. ${ }^{5} \mathrm{~A}$ high percentage of lung cancer occurs in former smokers, since the risk for lung cancer does not decline for many years following smoking cessation. ${ }^{6-10}$

Despite the predominance of tobacco smoking as its presumed etiology, lung cancer is also a significant health problem in those with no history of smoking. ${ }^{11,12}$ Emerging information supports the notion that lung cancer in never smokers is distinct enough from an epidemiologic and 
biologic standpoint to be considered a separate entity. ${ }^{13-16}$ Worldwide, lung cancer in never smokers comprises an estimated 15 to $20 \%$ of cases in men and over $50 \%$ in women. ${ }^{17}$ There are major geographic differences, particularly in Asia, where 60 to 80 percent of women with the disease are never smokers. ${ }^{11}$ Secondhand smoke is an important risk factor for lung cancer among never smokers. ${ }^{18-22}$ However, the extent of this problem is not clear. Several studies suggest that approximately 15 to $35 \%$ of lung cancer among never smokers is due to secondhand smoke, and that risk may be increased in those with exposure prior to age 25 . $^{23-27,28}$

Medical students are the backbone of health care of tomorrow. Their knowledge, attitude and practice directly correlate with the morbidity, mortality and the expenses of the patient. Medical students are expected to play a major role in the future physician-scientist workforce and act as visible role models and may unintentionally affect the behavior of others. The increasing of knowledge about cancer and also increasing prevalence of the disease warrants students to expand the horizon of the subject and also change their attitude towards the disease.

\section{METHODS}

Mixed, qualitative and quantitative approaches were used for data collection from 153 medical student of Kathmandu University School of Medical Sciences (KUSMS) from December 2011 to May 2012. Quantitative aspect of the study involved questionnaire based descriptive, cross sectional, survey study handed out to medical undergraduates of KUSMS among second, third and fourth year students; and qualitative part involved discussions carried out in three volunteer groups of ten students representing each medical year. Only MBBS undergraduates in their clinical year's education were approached as inclusion criteria. Of the total 180 students, 27 did not participate in either study, and only 30 students were approached for focused group discussion, to avoid data saturation. Sample size for the qualitative aspect was based on voluntary, random case selections among medical student.

Three separate groups of ten medical students each participated in group discussion. Medical students, were selected after they had filled the questionnaire portion of the study and time was limited to 15 minutes each and these were audiotaped. Group discussions were based on semi structured interviews related to tobacco, lung cancer and its epidemiology, prevention and cure. Transcribed transcripts were not returned to the respondents. From the transcripts we developed categories or themes. ${ }^{29}$ Sections of text were marked and linked to sections of text from other interviews that covered similar issues or experiences. ${ }^{30}$ Themes were considered in the context of all the interviews. ${ }^{31,32}$ Inter-rater reliability scores were not developed as the interviews had little structure-as such scores are not appropriate to data that have little or no predefined coding. ${ }^{33}$

The study is approved by the KUSMS Ethical board and follows all its rules, with approved consent taken from all medical students that participated. Descriptive statistical analysis was done using SPSS 11.0 for Windows PC (Statistical Package for Social Sciences, Chicago, Illinois).

\section{RESULTS}

\section{Study Demography}

Of the total 153 participants, 90 were male and 63 were females. Only 15 (10\%) have heard of Framework Convention on Tobacco Control (FCTC) in Nepal. Thirty one $(20.3 \%)$ were smokers and of them $6(3.9 \%)$ were exsmokers and remaining 122 did not smoke. All of those who smoke, have at least, once tried to cut back and succeeded on smoking control. Of the total, 114 (75\%) of responses knew all their friends that smoke tobacco and this knowledge was evenly divided among both gender. Sixty one (39.9\%) know/knew someone (friends/family) who had suffered from cancer of which 31 of them had family members who suffered from cancer and 6 know/ knew friends who suffered from cancer. (table 1)

Table 1. Demographic characteristics.

\begin{tabular}{|c|c|c|c|}
\hline Variable & Categories & $\begin{array}{l}\text { Number } \\
(n=153)\end{array}$ & \\
\hline \multirow[t]{2}{*}{ Gender } & Male & 93 & \\
\hline & Female & 60 & \\
\hline \multirow[t]{2}{*}{ Religion } & Hindu & 149 & \\
\hline & Buddhist & 4 & \\
\hline \multirow[t]{2}{*}{ Family Type } & Nuclear Family & 130 & \\
\hline & Joint Family & 23 & \\
\hline $\begin{array}{l}\text { Knowledge of } \\
\text { FCTC }\end{array}$ & Yes & 15 & \\
\hline \multirow[t]{2}{*}{$\begin{array}{l}\text { Know/Knew } \\
\text { someone with } \\
\text { Cancer }\end{array}$} & Yes & 61 & $\begin{array}{lc}\text { Friends } \quad 6 \\
\text { Family } \quad 31 \\
\text { Acquaintance } & 23\end{array}$ \\
\hline & No & 92 & \\
\hline \multirow{3}{*}{$\begin{array}{l}\text { *Top three } \\
\text { warning signs } \\
\text { of lung cancer }\end{array}$} & Sign One & Hemoptysis & \\
\hline & Sign Two & Chest Pain & \\
\hline & Sign Three & Weight Loss & \\
\hline
\end{tabular}

*As per the responses collected from the participants. FCTC - Framework Convention on Tobacco Control.

\section{Epidemiology of Lung Cancer}

Of the 14 signs/symptoms given, respondents were asked to identify the warning sign for cancer. Their responses summated and calculated percent wise on a scale of 70 . Ninety nine (58\%) of the responses had $80 \%$ or more knowledge of the 14 cancer warning signs, 62 (40.5\%) of the responses had average knowledge (60-80\%) of the 14 cancer warning signs, 18 of the respondents who are currently smoking have good knowledge of warning signs (>80\%). Of the 9 factors given, respondents were asked 
Table 2. Knowledge of Warning signs and risk factors - Likert Scale ( $n=153)$.

\begin{tabular}{|c|c|c|c|c|c|}
\hline & Strongly disagree (1) & $\begin{array}{l}\text { Disagree } \\
\text { (2) }\end{array}$ & $\begin{array}{l}\text { I don't know / } \\
\text { neutral (3) }\end{array}$ & $\begin{array}{l}\text { Agree } \\
\text { (4) }\end{array}$ & Strongly agree (5) \\
\hline \multicolumn{6}{|l|}{ Warning signs of Lung Cancer } \\
\hline Unexplained weight loss & - & 3 & 4 & 74 & 72 \\
\hline Persistent chest infection & 1 & 5 & 27 & 42 & 77 \\
\hline Cough that does not go away & 2 & 4 & 13 & 57 & 76 \\
\hline Shortness of breath & 1 & 7 & 13 & 52 & 78 \\
\hline Persistent tiredness & - & 4 & 23 & 41 & 83 \\
\hline Persistent chest pain & 2 & 9 & 22 & 36 & 83 \\
\hline Persistent shoulder pain & 3 & 20 & 79 & 16 & 34 \\
\hline Coughing up blood & - & 2 & 8 & 80 & 62 \\
\hline Ache or pain when breathing & 1 & 4 & 32 & 41 & 74 \\
\hline Loss of appetite & 1 & 1 & 12 & 63 & 76 \\
\hline Painful cough & 3 & 9 & 32 & 41 & 66 \\
\hline Changes in shape of finger (nail) & 2 & 6 & 29 & 60 & 55 \\
\hline High-pitched sound when breathing & 1 & 8 & 50 & 31 & 61 \\
\hline Change in existing cough pattern & 1 & 2 & 46 & 47 & 55 \\
\hline \multicolumn{6}{|l|}{ Risk factors for Lung Cancer } \\
\hline Cigarette smoke exposure & 4 & 3 & 5 & 105 & 36 \\
\hline Being a smoker & 4 & 1 & 7 & 88 & 53 \\
\hline Exposure to radon gas & 3 & 4 & 76 & 25 & 44 \\
\hline Past cancer treatment & 4 & 8 & 56 & 38 & 47 \\
\hline Close relative with lung cancer & 15 & 22 & 42 & 26 & 48 \\
\hline $\begin{array}{l}\text { Exposure to chemicals for example } \\
\text { asbestos }\end{array}$ & 1 & 2 & 15 & 74 & 61 \\
\hline Past history of head and neck cancer & 2 & 7 & 39 & 41 & 64 \\
\hline Air pollution & 2 & 9 & 11 & 47 & 84 \\
\hline $\begin{array}{l}\text { History of lung disease, for example } \\
\text { COPD }\end{array}$ & 5 & 17 & 30 & 39 & 61 \\
\hline
\end{tabular}

to identify the risk factors for cancer. Their responses summated and calculated percent wise on a scale of 45 . All participant identified smoking as one of the primary risk factors of lung cancer. Eighty two (53.59\%) of the responses had $80 \%$ or more knowledge of the 9 risk factors for cancer. Sixty nine (45\%) of the responses had average knowledge (60-80\%) of the 9 risk factors for cancer 12 of the respondents who are currently smoking have good knowledge of risk factors for smoking (knowledge level $>80 \%$ ). (table 2)

A mix picture seen regarding the epidemiological of lung cancer; with $75.3 \%$ believing that lung cancer was found more in developing countries like Nepal, and $16.2 \%$ believing its cause to be religious associated. Twenty six (26\%) percent believed that people may be immune to lung cancer and $14.9 \%$ said lung cancer to be inheritable. (table 3)

\section{Group Discussion}

Participants reported a range of interrelating factors that influenced smoking and steps that lead to lung cancer. Tobacco (smoke) was seen as the main cause of lung cancer, and lack of awareness and education was responsible for its prevalence. There seemed to be very less knowledge about
FCTC and this was attributed to inadequate advertisement, lack of awareness on passive smoking, and inadequate medical information relay. Group talks focused on some of the problems regarding smoking and lung cancer, along with some suggestions as outlined in table 4.

\section{DISCUSSION}

A hospital based study shows $16.4 \%$ prevalence of lung cancer in Nepal and in regional level of Pokhara, this is up to 20.9 \% with $\mathrm{Cl}$ (18.4-23.6) ${ }^{34-36}$ Lung cancer awareness study is important in Nepal, as the prevalence of smoking is as high as $38.4 \%$ as per global youth tobacco survey country report 2009. ${ }^{37}$ This study had 31 smokers, with 6 ex-smokers, among the medical students, and all of them were male. This is in lieu with other studies in Nepal, related to youth specific smoking status, where male smokers are predominant ${ }^{38,39}$ Since, all the participant were in medical/ health field, all identified smoking as health hazard and had tried to cut back on it.

Awareness of smoking as a primary risk factor for lung cancer was found to be $100 \%$ amongst all medical students. A study by Chawla et al. in Pokhara, Nepal in 2010 identifies 
Table 3. Knowledge of Epidemiology of Lung Cancer ( $n=153)$.

\begin{tabular}{|c|c|c|c|}
\hline Epidemiology & Yes \% & No $\%$ & I don't Know \% \\
\hline $\begin{array}{l}\text { Lung cancer is a common cancer } \\
\text { in Nepal. }\end{array}$ & 92.9 & 2.6 & 3.9 \\
\hline $\begin{array}{l}\text { Lung cancer is found more in } \\
\text { poor country like Nepal }\end{array}$ & 75.3 & 18.8 & 5.2 \\
\hline $\begin{array}{l}\text { Lung cancer occurs more com- } \\
\text { monly in old people. }\end{array}$ & 82.5 & 11 & 5.8 \\
\hline $\begin{array}{l}\text { Lung cancer can be inherited } \\
\text { from mother to daughter / } \\
\text { father to son }\end{array}$ & 14.9 & 53.9 & 30.5 \\
\hline $\begin{array}{l}\text { Lung cancer can be caused due } \\
\text { to disregard to religious/cultural } \\
\text { factors }\end{array}$ & 16.2 & 63.8 & 18.8 \\
\hline $\begin{array}{l}\text { Lung cancer happens to those } \\
\text { who are lazy }\end{array}$ & 5.2 & 86.4 & 7.8 \\
\hline $\begin{array}{l}\text { Lung cancer happens to those } \\
\text { who are heavy smokers }\end{array}$ & 95.5 & 3.9 & - \\
\hline $\begin{array}{l}\text { Lung cancer doesn't happen to } \\
\text { those who are light smokers }\end{array}$ & 11 & 74.7 & 13.6 \\
\hline $\begin{array}{l}\text { Lung cancer happens to those } \\
\text { who are fat }\end{array}$ & 5.8 & 65.6 & 27.9 \\
\hline $\begin{array}{l}\text { Some people are immune to } \\
\text { lung cancer }\end{array}$ & 26 & 39 & 33 \\
\hline \multicolumn{4}{|l|}{ Diagnosis and Treatment } \\
\hline $\begin{array}{l}\text { Cancer can be detected in early } \\
\text { stage }\end{array}$ & 72.7 & 18.2 & 8.4 \\
\hline $\begin{array}{l}\text { Lung cancer can be detected in } \\
\text { early stage }\end{array}$ & 64.9 & 21.4 & 13 \\
\hline $\begin{array}{l}\text { Lung cancer can be treated if } \\
\text { detected in early stage }\end{array}$ & 81.2 & 7.8 & 10.4 \\
\hline $\begin{array}{l}\text { Observing one's smoking habit } \\
\text { and controlling it } \\
\text { to minimum is useful in early } \\
\text { detection of lung cancer }\end{array}$ & 7.08 & 12.3 & 16.2 \\
\hline $\begin{array}{l}\text { Surgery is the only treatment } \\
\text { available for lung cancer }\end{array}$ & 20.7 & 55.8 & 22.7 \\
\hline $\begin{array}{l}\text { Early detection improves the } \\
\text { outcome of treatment }\end{array}$ & 95.5 & 2.6 & 1.3 \\
\hline $\begin{array}{l}\text { There are few oral medication to } \\
\text { treat lung cancer }\end{array}$ & 50.6 & 13.6 & 35.1 \\
\hline
\end{tabular}

this knowledge on non-medical population at $100 \%$ amongst male and $88 \%$ among female. ${ }^{39}$ The prevalence of smoking among medical students appears to vary widely from country to country. From literature review it appears that smoking rates among male medical students range between $3 \%$ in the United States and $58 \%$ in Japan. ${ }^{40,41}$ Smoking prevalence rates below $10 \%$ of the medical student population were shown to occur in Australia (4$6 \%)$, China (6\%), India (7\%), Thailand (7\%), the US (7\%) and Malaysia (9\%). ${ }^{40,42-47}$ Marked differences in smoking rates were found by gender in almost all studies, with male students generally having the higher rates. Fifteen percent of responses were aware of the lung cancer as hereditary factor in the causation of the disease. A study by Swartz in 1996 has shown 6.1 fold increases in the incidence of lung cancer in families in which the proband (a patient who is the initial member of a family to come under study) contracted lung cancer between the age of $40-59$ years..$^{39,48}$
Table 4. Topic and Solutions suggested during qualitative data collection - via group discussion.

\begin{tabular}{|c|c|c|}
\hline Topic & Solution & Group \\
\hline \multirow{3}{*}{$\begin{array}{l}\text { Tolerance for } \\
\text { public smok- } \\
\text { ing }\end{array}$} & $\begin{array}{l}\text { Cultural Awareness should be } \\
\text { strengthened }\end{array}$ & Group 1, 3 \\
\hline & $\begin{array}{l}\text { Media (Television, Radio, Internet, } \\
\text { Newspaper) led awareness should be } \\
\text { carried out }\end{array}$ & Group 2, 3 \\
\hline & Priority on School Health education & Group 1,2 3 \\
\hline \multirow[t]{3}{*}{$\begin{array}{l}\text { Tolerance } \\
\text { for passive } \\
\text { smoking }\end{array}$} & $\begin{array}{l}\text { Media (Television, Radio, Internet, } \\
\text { Newspaper) led awareness should be } \\
\text { carried out }\end{array}$ & Group 2 \\
\hline & Priority on School Health education & Group 1, 2, 3 \\
\hline & $\begin{array}{l}\text { Priority on Office/Work place health } \\
\text { education }\end{array}$ & Group 3 \\
\hline \multirow[t]{4}{*}{$\begin{array}{l}\text { Lack of knowl- } \\
\text { edge on FCTC } \\
\text { rule in Nepal }\end{array}$} & $\begin{array}{l}\text { Media (Television, Radio, Internet, } \\
\text { Newspaper) led awareness should be } \\
\text { carried out }\end{array}$ & Group 1, 2 ,3 \\
\hline & $\begin{array}{l}\text { Pamphlets and posters in public } \\
\text { places }\end{array}$ & Group 1, 2,3 \\
\hline & Priority on School Health education & Group 1, 2 ,3 \\
\hline & $\begin{array}{l}\text { Information dissemination on public/ } \\
\text { private properties }\end{array}$ & Group 2,3 \\
\hline \multirow[t]{2}{*}{$\begin{array}{l}\text { Lung cancer } \\
\text { diagnosis and } \\
\text { its treatment }\end{array}$} & $\begin{array}{l}\text { Media (Television, Radio, Internet, } \\
\text { Newspaper) led awareness should be } \\
\text { carried out }\end{array}$ & Group 1, 2 \\
\hline & $\begin{array}{l}\text { Information centers on Health } \\
\text { Institution }\end{array}$ & Group 1, 2, 3 \\
\hline \multirow[t]{2}{*}{$\begin{array}{l}\text { Awareness in- } \\
\text { tervention for } \\
\text { lung cancer }\end{array}$} & $\begin{array}{l}\text { Media (Television, Radio, Internet, } \\
\text { Newspaper) led awareness should be } \\
\text { carried out }\end{array}$ & Group 1, 3 \\
\hline & $\begin{array}{l}\text { Support groups for lung cancer } \\
\text { patient/survivors }\end{array}$ & Group 1, 2, 3 \\
\hline
\end{tabular}

Regarding qualitative data from the 30 medical students interviewed, it was encouraging to note that no medical students reported that they began smoking after joining medical school. Our expectation of increased quit rates as the students progressed through their education the increasing knowledge about adverse effects of smoking and increased patient contact was seen with little changes in smoking habits, plans to quit, during the course of medical education, which consistent with studies that have found that medical and nursing students' smoking habits were not modified by their education programs. ${ }^{49-51}$ However, the findings should be considered preliminary since our survey was cross-sectional, the numbers of former smokers were small, and definitive conclusions may require longitudinal studies with larger sample sizes. Students had adequate knowledge regarding epidemiological information on lung cancer, but lacked local and national policies for smoking and lung cancer prevention and cure. ${ }^{52}$ All agreed on extensive prevalence of cultural tolerance for smokers in Nepali society, and the lack of awareness regarding passive smoking and its effects.

Results from this study must be interpreted in light of the limitations of a self-report survey design. These include recall and nonresponse bias and reporting errors. The main limitation was that approximately $27(15 \%)$ of sample 
did not return the survey, introducing a non-responder bias that may have affected the findings. Also, due to our attempt to maintain anonymity, the possibility of some degree of duplication of surveys cannot be excluded. A follow-up study recommended with more comprehensive and longitudinal assessment of smoking habits of medical students during their medical school years.

\section{CONCLUSION}

In conclusion, knowledge about lung cancer and smoking is relatively stable among medical students of KUSMS. Study finds that, medical students who currently smoke have tried to leave smoking in past. Results emphasize the need to strengthen health education programs that enhance

\section{REFERENCES}

1. Jemal A, Bray F, Center MM, Ferlay J, Ward E, Forman D. Global cancer statistics. CA Cancer J Clin 2011;61:69-90.

2. Siegel R, Ward E, Brawley O, Jemal A. Cancer statistics, 2011: The impact of eliminating socioeconomic and racial disparities on premature cancer deaths. CA Cancer J Clin 2011; 61:212-36.

3. Molina JR, Adjei AA, Jett JR. Advances in chemotherapy of non-small cell lung cancer. Chest 2006; 130:1211-9.

4. Wakai K, Marugame T, Kuriyama S, Sobue T, Tamakoshi A, Satoh H, et al. Decrease in risk of lung cancer death in Japanese men after smoking cessation by age at quitting: pooled analysis of three largescale cohort studies. Cancer Sci 2007 Apr;98(4):584-9.

5. Alberg AJ, Samet JM. Epidemiology of lung cancer. Chest 2003; 123:21S-49S.

6. Burns DM. Primary prevention, smoking, and smoking cessation: implications for future trends in lung cancer prevention. Cancer 2000; 89:2506-9.

7. Halpern MT, Khan ZM, Young TL, Battista C. Economic model of sustained-release bupropion hydrochloride in health plan and work site smoking-cessation programs. Am J Health Syst Pharm 2000; 57:1421-9.

8. Halpern MT, Gillespie BW, Warner KE. Patterns of absolute risk of lung cancer mortality in former smokers. J Natl Cancer Inst 1993; 85:45764.

9. Tong L, Spitz MR, Fueger JJ, Amos CA. Lung carcinoma in former smokers. Cancer 1996; 78:1004.

10. Fontham ET, Correa P, Reynolds P, Wu-Williams A, Buffler PA, Greenberg RS. Environmental tobacco smoke and lung cancer in nonsmoking women. A multicenter study. JAMA 1994; 271:1752-9.

11. Sun S, Schiller JH, Gazdar AF. Lung cancer in never smokers--a different disease. Nat Rev Cancer 2007; 7:778.

12. Subramanian J, Govindan R. Lung cancer in never smokers: a review. J Clin Oncol 2007; 25:561.

13. Yano T, Miura N, Takenaka T, Haro A, Okazaki H, Ohba T, et al. Never-smoking nonsmall cell lung cancer as a separate entity: clinicopathologic features and survival. Cancer 2008; 113:1012-8.

14. Subramanian J, Govindan R. Molecular genetics of lung cancer in people who have never smoked. Lancet Oncol 2008; 9:676.

15. Subramanian J, Govindan R. Lung cancer in 'Never-smokers': a unique entity. Oncology (Williston Park) 2010; 24:29.

16. Rudin CM, Avila-Tang E, Harris CC, Herman JG, Hirsch FR, Pao W, et al. Lung cancer in never smokers: molecular profiles and therapeutic implications. Clin Cancer Res 2009; 15:5646-61. tobacco and lung cancer knowledge among students. Awareness to non-medical population via social marketing is a way of developing education messages which tackle cultural influences on tobacco and its cause leading to lung cancer and for these medical students have a potential role in developing and disseminating messages.

\section{ACKNOWLEDGEMENT}

Authors would like to appreciate the help from members of Kathmandu University Teaching Hospital (KUTH), Department of Medicine - Professor Dr. Bedi, Dr. Shudeip Shrestha, Dr Rajendra Tamrakar for their valuable suggestions and input to this study.

17. Parkin DM, Bray F, Ferlay J, Pisani P. Global cancer statistics, 2002. CA Cancer J Clin 2005; 55:74.

18. Peto R, Darby S, Deo H. Smoking, smoking cessation, and lung cancer in the UK since 1950: combination of national statistics with two casecontrol studies. BMJ 2000; 321:323.

19. Nyberg F, Agudo A, Boffetta P. A European validation study of smoking and environmental tobacco smoke exposure in nonsmoking lung cancer cases and controls. Cancer Causes Control 1998; 9:173.

20. Brennan P, Buffler PA, Reynolds P. Secondhand smoke exposure in adulthood and risk of lung cancer among never smokers: a pooled analysis of two large studies. Int J Cancer 2004; 109:125.

21. Gorlova OY, Zhang Y, Schabath MB, et al. Never smokers and lung cancer risk: a case-control study of epidemiological factors. Int $J$ Cancer 2006; 118:1798.

22. Vineis P, Airoldi L, Veglia F. Environmental tobacco smoke and risk of respiratory cancer and chronic obstructive pulmonary disease in former smokers and never smokers in the EPIC prospective study. BMJ 2005; 330:277.

23. Wu A. Carcinogenic effects. In: Health Effects of Exposure to Environmental Tobacco Smoke, Shopland DR, Zeise L, Dunn A (Eds), National Cancer Institute, Bethesda, MD 1999.

24. Vineis $P$, Alavanja $M$, Buffler $P$. Tobacco and cancer: recent epidemiological evidence. J Nat/ Cancer Inst 2004; 96:99.

25. IARC Working Group on the Evaluation of Carcinogenic Risks to Humans. Tobacco smoke and involuntary smoking. IARC Monogr Eval Carcinog Risks Hum 2004; 83:1.

26. Vineis P, Hoek G, Krzyzanowski M. Lung cancers attributable to environmental tobacco smoke and air pollution in non-smokers in different European countries: a prospective study. Environ Health 2007; 6:7.

27. Clément-Duchêne $C$, Vignaud JM, Stoufflet A. Characteristics of never smoker lung cancer including environmental and occupational risk factors. Lung Cancer 2010; 67:144.

28. Asomaning K, Miller DP, Liu G. Second hand smoke, age of exposure and lung cancer risk. Lung Cancer 2008; 61:13.

29. Pope C, Ziebland S, Mays N. Analysing qualitative data. BMJ 2000;320:114-6.

30. Richards L, Richards T. The transformation of qualitative method: computational paradigms and research processes. In: Fielding $\mathrm{N}$, Lee $\mathrm{R}$, eds. Using computers in qualitative research. London: Sage 1993:38-53.

31. Tesch R. Qualitative research: analysis types and software tools. New York: Falmer, 1991. 
32. Malterud K. Qualitative research: standards, challenges, and guidelines. Lancet 2001;358:483-8.

33. Morse JM. "Perfectly healthy but dead:" the myth of inter-rater reliability. Qual Health Res 1997;7:445-7.

34. BPKM Cancer Hospital. 2010 Annual Report. BP Koirala Memorial Cancer Hospital, Bharatpur, Nepal;2010.

35. Chapagain SA. Cancer in Nepal. My Republica [Internet]. [Last accesses on July 17, 2012] [Available from: http://www.myrepublica. com/portal/index.php?action=news_details\&news_id=16896].

36. Sathian B, Bhatt CR, Jayadevan S Prediction of cancer cases for a hospital in Nepal: a statistical modelling. Asian Pac J Cancer Prev 2010;11:441-5

37. World Health Organization. Tobacco Free Initiative - Regional Tobacco control database. WHO Nepal. 2009. [Available from: http://www. searo.who.int/en/Section1174/Section2469/Section2481.htm].

38. Binu VS, Subba SH, Menezes RG. Smoking among Nepali youthprevalence and predictors. Asian Pac J Cancer Prev 2010;11:221-6.

39. Chawla R, Sathian B, Mehra A, Kiyawat V, Garg A, Sharma K. Awareness and Assessment of Risk Factors for Lung Cancer in Residents of Pokhara Valley. Asian Pacific Journal of Cancer Prevention 2010;11:1789-93.

40. Mangus RS, Hawkins CE, Miller MJ. Tobacco and alcohol use among 1996 medical school graduates. JAMA 1998;280:1192-3,5.

41. Kawane H. Antismoking education for medical students. Chest 1992;101:1480.

42. Roche AM. Have efforts to improve medical students' drug and alcohol knowledge, skills and attitudes worked?. Drug Alcohol Rev 1997;16:157-70.
43. Lei $\mathrm{Z}$, Jingheng $\mathrm{H}$, Jianzhong $\mathrm{L}$. Smoking among Shanghai medical students and the need for comprehensive intervention strategies. Health Promot Int 1997;12:27-32.

44. Roy M, Chakraborty AK. Smoking and drug-abuse among the newly admitted students of medical colleges in West Bengal. Indian J Public Health 1981;25:30-5.

45. Songkla YN, Saenghirunvattana S. Smoking among medical students. J Med Assoc Thailand 1985;68:198-200.

46. Najem GR, Passannante MR, Foster JD. Health risk factors and health promoting behavior of medical, dental and nursing students. J Clin Epidemiol 1995;48:841-9.

47. Yaacob I, Abdullah ZA. Smoking behavior, knowledge and opinion of medical students. Asia Pac J Public Health 1994;7:88-91.

48. Schwartz AG, Yang P, Swanson GM. Familial risk of lung cancer among nonsmoker and their relatives. Am J Epidemiol 1996;144:554-62.

49. Gillmann-Blum D, Castillo-Hofer C, Ferlinz R. Does medical study change behavior, attitude and knowledge about smoking? A survey of medical students in the first and next to last year of the study. Pneumologie 1990; 44:515-516

50. Boccoli E, Federici A, Trianni GL. Changes of smoking habits and beliefs during nurse training: a longitudinal study. Eur J Epidemiol 1997; 13:899-902

51. Patkar AA, Hill K, Batra V. A Comparison of Smoking Habits Among Medical and Nursing Students. CHEST 2003; 124:1415-20.

52. World Health organization. World No Tobacco Day (WNTD), 31 May, 2011. Kathmandu, Nepal. [Available from: http://www.nep.searo. who.int/EN/Section1_242.htm]. 